\title{
KONEKTIVITAS ANGKUTAN KERETA API DENGAN ANGKUTAN JALAN ( STUDI KASUS : STASIUN CIBITUNG, BEKASI )
}

\author{
Subarto, ATD,MM \\ Dosen STTD
}

Jl. Raya Setu No. 89, Bekasi

Telp./Fax : (021) 8254640

\author{
Ir. Jamal Subastian, M.Sc \\ Dosen STTD \\ J1. Raya Setu No. 89, Bekasi \\ Telp./Fax : (021) 8254640
}

\author{
DR. Gloria Novita C, MT \\ Dosen STTD \\ Jl. Raya Setu No. 89, Bekasi \\ Telp./Fax : (021) 8254640
}

\author{
Abadi Sastrodiyoto, SH,MH \\ Dosen STTD \\ Jl. Raya Setu No. 89, Bekasi \\ Telp./Fax : (021) 8254640
}

\begin{abstract}
Railway transportation is an important part of the public transport system in Indonesia and is one of the elements of an urban transportation system that plays a very important role for an area or region. One indicator of the region that can be marked, among others, is by looking at the condition of the transportation system, especially public transport. In addition, good public transport routes must be able to reach all regions and meet the interests of several related parties such as passengers, managers and government, but in order to be more optimal, rail transport must be supported by public transport services. road-based so as to create connectivity between various types of services.
\end{abstract}

Keywords: Railroad, passenger, manager, government

\begin{abstract}
Abstraksi
Angkutan kereta Api sebagai bagian penting dari sistim angkutan umum di Indonesia dan merupakan salah satu elemen dari sistem transportasi perkotaan yang memegang peran yang sangat penting bagi suatu daerah atau wilayah. Salah satu indikator dari wilayah yang dapat ditandai, antara lain dengan melihat kondisi sistem transportasi khususnya angkutan umumnya. Di samping itu, rute angkutan umum yang baik harus dapat dapat menjangkau seluruh wilayah dan memenuhi kepentingan beberapa pihak terkait seperti penumpang (user), pengelola (operator) dan pemerintah (regulator), namun agar lebih optimal angkutan KA harus didukung oleh peyanan angkutan angkutan umum berbasis jalan sehingga tercipta konektivitas antara berbagai jenis pelayanan.
\end{abstract}

Kata Kunci : Kereta Api,penumpang,pengelola,pemerintah 


\section{PENDAHULUAN}

\section{LATAR BELAKANG}

Karakter wilayah Kabupaten Bekasi yang luas dan sebaran penduduk yang relatif merata dan dimana sebagaian besar penduduknya bekerja diluar kota atau di wilayah Jabotabek menyebabkan adanya kebutuhan terhadap angkutan umum yang memiliki karakteristik perjalanan yang cukup panjang, sehingga diperlukan jenis angkutan yang dapat melayani perjalanan jarak jauh, melihat kondisi lalu lintas dan kondisi jaringan jalan yang kurang baik menyebabkan pelayanan angkutan umum dengan basis jalan menjadi kurang optimal, sehingga adanya pelayanan angkutan kereta api (KA) menjadi sangat penting.

Di samping itu, rute angkutan umum yang baik harus dapat dapat menjangkau seluruh wilayah dan memenuhi kepentingan beberapa pihak terkait seperti penumpang (user), pengelola (operator) dan pemerintah (regulator), namun agar lebih optimal angkutan KA harus didukung oleh peyanan angkutan angkutan umum berbasis jalan sehingga tercipta konektivitas antara berbagai jenis pelayanan.

\section{MAKSUD DAN TUJUAN}

\section{Maksud}

Secara umum maksud dari studi ini dimaksudkan untuk mengumpulkan data dan menganalisa tingkat konektivitas angkutan kereta api dengan angkutan lainnya di Stasiun Cibitung.

\section{Tujuan}

Tujuan yang diharapkan dalam pekerjaan ini adalah dapat digunakan oleh instansi terkait untuk digunakan sebagai acuan dalam meningkat pelayanan angkutan umum di Kabupaten Bekasi; 


\section{SASARAN}

Sasaran utama studi ini lebih diarahkan sebagai bahan evaluasi dalam penetapan kebijakan perencanaan, angkutan jalan (trayek) yang berbasis pada konektivitas pelayanan kereta api pada Stasiun Cibitung.

\section{PENGUMPULAN DATA}

Terdapat 2 (dua) data yang diperlukan dalam melakukan studi di bidang transportasi yang akan diolah lebih lanjut secara ilmiah dengan melakukan analisis-analisis dengan metode-metode yang dapat diterima secara ilmiah untuk mengetahui kondisi eksisting, mengidentifikasi permasalahan dan membantu pengambilan keputusan dan penyusunan rekomendasi untuk mengatasi permasalahan. Adapun kedua jenis data tersebut adalah

\section{Metoda Analisis}

Tahap ini merupakan tahap untuk mengidentifikasi masalah dan pemecahannya. Langkah analisis untuk mencari pemecahan masalah merupakan tahapan terakhir dalam lingkup pekerjaan yang akan dilakukan, dimana pada langkah ini akan dilakukan perhitungan-perhitungan dengan pendekatan teoritis dan legalitas serta dengan memperhatikan kebijakan-kebijakan pemerintah yang ada.

Suatu analisa akan lebih dapat dipertanggungjawabkan bila didukung oleh kemampuan sumber daya manusia dalam melakukan analisa serta yang terpenting adalah kuantitas dan kualitas data yang ada yang menjadi objek analisa. Oleh karena itu sangat diperlukan persiapan dalam hal sumber daya manusianya serta teknik perolehan data yang dapat dipertanggungjawabkan serta sesuai dengan data dilapangan.

Untuk mengetahui karakteristik lalulintas di daerah kajian dirasakan perlu untuk melalukan peninjauan lapangan, hal ini untuk mengantisipasi adanya perubahan yang akan terjadi setiap saat dan bersifat dinamis oleh karenanya terkadang akan ada kecenderungan perbedaan dari data yang diperoleh melalui survey dengan kondisi sebenarnya. Data hasil survai inventarisasi dan wawacara angkutan umum dianalisis 
untuk mendapatkan gambaran karakteristik perjalanan denga menggunakan comuter line akan ditampilkan dalam bentuk tabulasi, grafik dan peta yang informatif.

Adapun metode-metode analisis adalah sebagai berikut :

\section{Sebaran perjalanan}

Diperlukan data tentang sebaran perjalanan untuk mendapatkan data karakteristik perjalanan dari dan ke stasiun cibitung

\section{Jumlah sebaran Penumpang}

Untuk mendapatkan jumlah sebaran penumpang sehingga dapat diukur kebutuhan kendaraan sehingga dapat diperkirakan kendaraan sesuai dengan jumlah kendaraan pada tiap trayek yang disurvai.

\section{Matrik asal Tujuan}

Dari semua data diatas dan dikaitkan dengan zona daerah study maka akan dapat disusun matrik asal tujuan yang menggambarkan sebaran perjalanan dan besarnya nilai perjalanan, sehingga dapt disusun rencana jaringan perjalanan angkutan umum jika belum ada jaringan trayek dan peningakatan pelayanan jika sudah dilayani oleh angkutan umum.

\begin{tabular}{|c|c|c|c|c|c|c|c|}
\hline $\begin{array}{c}\text { Tujuan } \\
\text { Asal (dari) }\end{array}$ & 1 & 2 & 3 & 4 & 5 & 6 & $\begin{array}{l}\text { Total } \\
\text { O, }\end{array}$ \\
\hline 1 & 200 & 700 & 300 & -- & 240 & --- & 1440 \\
\hline 2 & 300 & 200 & --- & 300 & 400 & --- & 1200 \\
\hline 3 & 450 & --- & 350 & --- & 460 & -- & 1260 \\
\hline 4 & --- & --- & $-\cdots$ & 300 & --- & 500 & 800 \\
\hline 5 & 200 & 400 & 300 & 300 & 100 & 600 & 1900 \\
\hline 6 & --- & --- & --- & 300 & 400 & 200 & 900 \\
\hline$D_{j}$ & 1150 & 1300 & 950 & 1200 & 1600 & 1300 & 7500 \\
\hline
\end{tabular}

\section{Tingkat Operasi}

Tingkat operasi dihitung dengan 2 (dua) cara yakni dengan menggunakan data hasil survai statis dan dengan menggunakan asumsi dasar bahwa hari kerja atau hari operasi per tahun. 
Dengan menggunakan asumsi hari kerja per tahun 300 hari, maka tingkat operasi adalah

$$
T O=\frac{300}{365} \times 100 \%=82,2 \%(\text { dibulatkan menjadi } 80 \%=292 \text { hari })
$$

\section{PENGUMPULAN DATA}

Terdapat 2 (dua) data yang diperlukan dalam melakukan studi di bidang transportasi yang akan diolah lebih lanjut secara ilmiah dengan melakukan analisis-analisis dengan metode-metode yang dapat diterima secara ilmiah untuk mengetahui kondisi eksisting, mengidentifikasi permasalahan dan membantu pengambilan keputusan dan penyusunan rekomendasi untuk mengatasi permasalahan. Adapun kedua jenis data tersebut adalah:

\section{Data Sekunder}

Data Sekunder adalah data-data yang sudah ada di instansi-intansi terkait dan diperoleh tanpa melakukan pengamatan lapangan. Data ini digunakan untuk mendukung pengumpulan data primer dan digunakan untuk proses analisis. Data Sekunder yang diperlukan dalam penelitian ini adalah:

1) Peta Wilayah Studi (Peta Kabupaten Bekasi);

2) Data dan Peta Jaringan Jalan;

3) Data dan Peta Jaringan Trayek;

4) Data Rencana Tata Ruang Wilayah (RTRW);

5) Data Kabupaten Bekasi dalam angka (data jumlah kendaraan, data pertumbuhan penduduk, data pertumbuhan lalu lintas dan demografi);

6) Data kegiatan stasiun cibitung;

7) Data pergerakan angkutan KA

\section{Data Primer}

Data Primer adalah data-data yang diperoleh dengan cara melakukan Survey wawancara dengan form sebagaimana terlampir. 
Data Primer yang diperlukan dalam Studi Evaluasi dan Penataan Jaringan Trayek ini adalah data-data yang diperoleh dengan melakukan survei-survei sebagai berikut ini

\section{Survei Inventarisasi Stasiun.}

Survei Inventarisasi dilakukan untuk mengetahui kondisi lapangan tempat dilaksanakannya berbagai survei untuk memperoleh data-data sekunder.

Dalam survei ini ditentukan titik-titik lokasi survei yang aman, nyaman dan sedapat mungkin terlindung dari gangguan cuaca, selain itu dalam survei pengenalan lapangan tersebut juga dapat dilakukan uji coba formulir-formulir survei yang sudah dibuat agar pada saat pelaksanaan survei tidak lagi terdapat kesulitan dalam pengisian formulir-formulir tersebut.

\section{Survei Wawancara penumpang KA}

Survei ini dilakukan untuk mengetahui sebaran perjalanan setelah dan sebelum calon penumpang berada di stasiun.

\section{Tujuan}

Tujuan survei ini adalah :

- Mengetahui data perjalanan sebelum menuju stasiun dan setelah meninggalkan stasiun;

- Mengetahui jumlah perjalanan.

- Mengetahui karakteristik perjalanan.

\section{Target Data}

Target data yang akan dikumpulkan adalah :

- Lamanya menggunakan CL

- Sifat perjalanan

- Asal dan tujuan perjalanan

- Panjang rute tiap trayek;

- Tujuan Perjalanan

- dll. 


\section{Metoda Analisis}

Tahap ini merupakan tahap untuk mengidentifikasi masalah dan pemecahannya. Langkah analisis untuk mencari pemecahan masalah merupakan tahapan terakhir dalam lingkup pekerjaan yang akan dilakukan, dimana pada langkah ini akan dilakukan perhitungan-perhitungan dengan pendekatan teoritis dan legalitas serta dengan memperhatikan kebijakan-kebijakan pemerintah yang ada.

Suatu analisa akan lebih dapat dipertanggungjawabkan bila didukung oleh kemampuan sumber daya manusia dalam melakukan analisa serta yang terpenting adalah kuantitas dan kualitas data yang ada yang menjadi objek analisa. Oleh karena itu sangat diperlukan persiapan dalam hal sumber daya manusianya serta teknik perolehan data yang dapat dipertanggungjawabkan serta sesuai dengan data dilapangan.

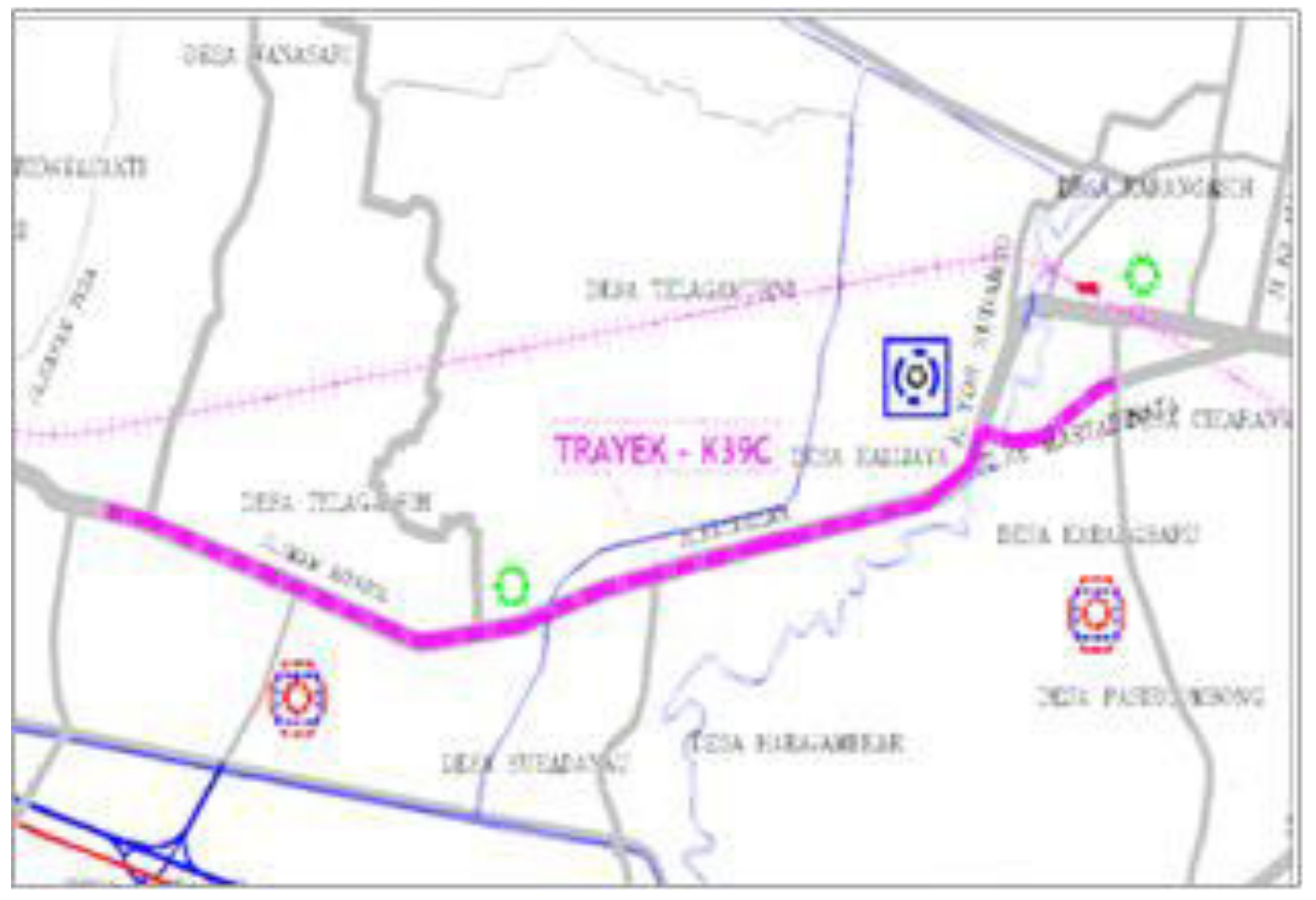

Gambar. Lintasan Trayek K-39-C 


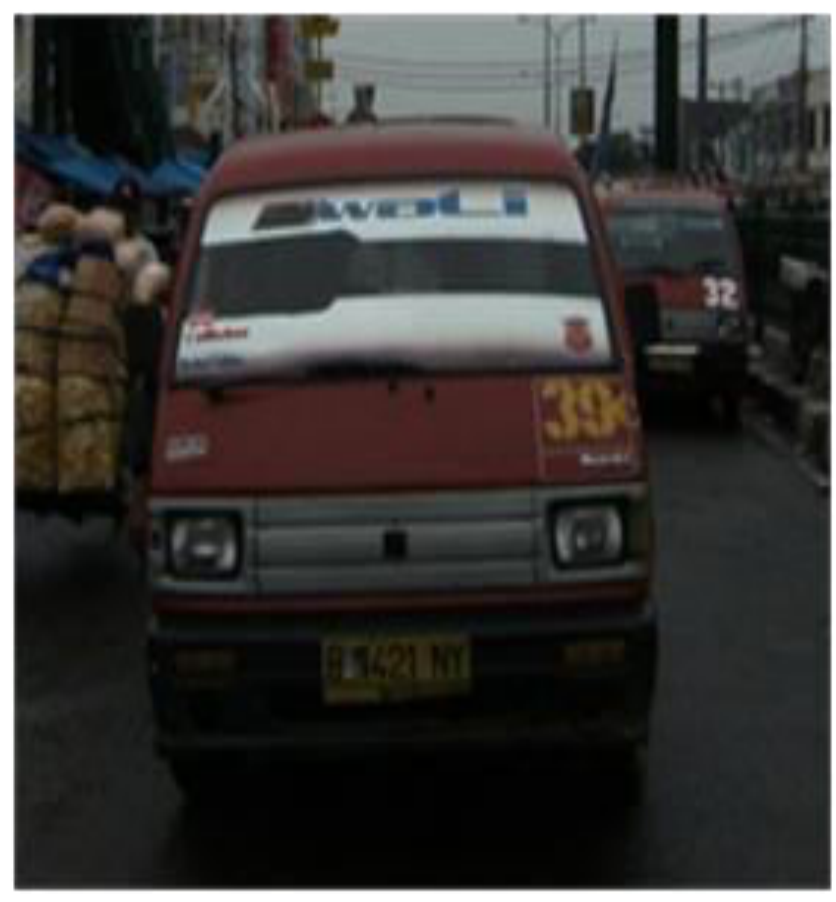

\begin{tabular}{|ll|ll|}
\hline TIPE KENDARAAN & $:$ MINIBUS & JUMLAH RIT PER HARI & $: 7$ \\
KAPASITAS & $: 12$ & TARIF & $: 2500$ \\
UMUR RAT-RATA & $: 8$ TAHUN & KEPEMILIKAN & $:$ PERORANGAN \\
\hline
\end{tabular}

\section{Gambar Jenis Sarana angkutan yang melayani Trayek K-39 C}

Data taryek angkutan kota yang melewati stasiun Cibitung.

AKDP Cikarang - Bekasi - Pulo Gadung (via Cibitung)

KOASI Kab. Bekasi K.01A Cikarang - Bekasi (via Cibitung - Tambun - Bulak Kapal)

KOASI Kab. Bekasi K36A Cikarang-CBL (via Cibitung)

\section{PENGUMPULAN DATA PRIMER}

Untuk mendukung data-data sekunder yang telah diperoleh dan untuk mendapatkan gambaran mengenai kondisi angkutan umum di kabupaten Bekasi, maka pengumpulan data primer akan dilakukan secara langsung dengan tujuan memperoleh informasi penting berkaitan dengan unjuk kerja angkutan umum. 
Sebelum survai primer, terlebih dahulu dilakukan tahap persiapan survai yang intinya mendayagunakan sumber daya perolehan informasi sekunder bagi kematangan pelaksanaan survai primer. Pada tahap ini segala informasi yang berkaitan dengan masalah lapangan pada wilayah kajian diramu dengan peta-peta serta teori idealisasi sasaran analisis dan diterjemahkan ke dalam bentuk-bentuk formulir survai, rencana kerja survai, organisasi lapangan, dan peta-peta detail.

Pelaksanaan waktu survai dilaksanakan pada jam sibuk pagi, jam tidak sibuk, maupun jam sibuk sore.

Pelaksanaan survai wawancara dilaksanakan selama 3 (tiga) hari, hari pertama dan kedua merupakan hari jam kerja yaitu pada hari selasa tanggal 18 dan 19 September 2018 (Pukul 06.00 s.d. 18.00) dan hari ketiga pada hari libur kerja yaitu hari minggu tanggal 23 September 2018 (Pukul 06.00 s.d. 18.00). Pelaksanaan survey dilakukan di dalam Stasiun Cibitung.

Melihat hasil evaluasi dan kondisi pelayanan serta volume permintaan angkutan penumpang umum di Kabupaten Bekasi, terdapat beberapa hal yang dapat direkomendasikan antara lain:

1) Melakukan kajian optimalisasi moda angkutan yang sesuai dengan karakteristik permintaan di Kabupaten Bekasidan melakukan evaluasi ulang jumlah kebutuhan trayek pada masing-masing trayek dengan potensi permintaan penumpang yang ada sekarang (indikasi jumlah kendaraan yang beroperasi jauh diatas kendaraan yang diizinkan) sehingga load faktor ratarata kendaraan angkutan umum di dibawah $40 \%$ karena Jumlah penawaran (supply) angkutan umum lebih besar dibanding permintaan (demand).

2) Memperhatikan banyaknya penyimpangan trayek dan tingkat tumpang tindih/berimpit trayek angkutan umum yang sudah tidak ideal, maka Pemerintah Daerah kabupaten Bekasi perlu melakukan Penataan ulang jaringan trayek sehingga taryek yang diusulkan lebih efektif dan efisien baik dari segi penumpang maupun dari segi pemerintah. 
3) Untuk angkutan umumberkaitan dengan peningkatan Stasiun Cibitung.

a) Untuk pergerakan jarak jauh dan memengah sudah cukup dijangkau oleh angkutan umum yang ada yaitu Angkutan K01 dan Angkutan AKDP $3 / 4$ untuk pergerakan di jalur utama Kabupaten Bekasi.

b) Sedangkan untuk wilayah menengah pada kisaran zona atau kecamatan sekitar Stasiun Cibitung sudah dapat dilayani oleh angkutan K.39c.

c) Yang menjadi masalah adalah banyak nya perumahan dalam kecamatan cibitung yang belum terlayani oleh angkutan umum.

Untuk itu diusulkan adanya penambahan trayek baru yang melayani penumpang pada wilayah sekitar stasiun cibitungyaitu tarayek T1 dan T2:

Trayek 1: T1: Sta. Cibitung - Selang Ciu- Putra Dharma - Sumber Jaya CBL - Selang Bojong- Pasar Pamor - Jl. Bosih - Sta. Cibitung.

Trayek 2: T2: Sta. Cibitung- Perum Pesona- Metland - Sta. Cibitung- SelangTeuku Umar - Sta. Cibitung

4) Untuk mendukung peningkatan pelayanan kepada penumpang angkutan umum, khususnya yang akan menggunakan angkutan kereta api, maka perlu disediakan fasilitas pejalan kaki, pada lokasi-lokasi perpindahan penumpang dari angkutan umum jalan ke angkutan umum jalan lainnya, maupun dari angkutan umum jalan ke angkutan kereta api. Pada kasus Stasiun Cibitung adalah pada lokasi:

a. Pada persimpangan jalan Teuku Umar Raya dengan Jalan Bosih Raya; dan

b. Pada loaksi di depan stasiun Cibitung, di Jalan Bosih raya. 


\section{DAFTAR PUSTAKA}

Kanafani, A., 1983, Transportation Demand Analysis, McGraw-Hill, New York

Nazir, 1988, MetodePenelitian, Ghalia Indonesia, Jakarta

Papacostas, C.S. and Prevedouros, P.D., 1993, Transportation Engineering and Planning Second Edition, Prentice Hall.

Sugiyono,2007, StatistikUntukPenelitian, Edisikeduabelas, Alfabeta, Bandung.

2009, UndangUndangNomor $22 \quad$ Tahun 2009

TentangLalulintasdanAngkutanJalan,Jakarta.

...2013, PeraturanPemerintahNomor $\quad 79 \quad$ Tahun 2013

TentangJaringanLaluLintasdanAngkutanJalan, Jakarta

2014, PeraturanPemerintahNomor 74 Tahun 2014 tentangAngkutanJalan, Jakarta

2016, PeraturanMenteriNomor 16 Tahun 2016 dijelaskanbahwa drop zonel pick up point, Jakarta

1996, KeputusanDirekturJenderalPerhubunganDaratNomor 271 Tahun 1996

tentangPedomanTeknisPerekayasaanTempatPerhentianKendaraanPenump angUmum, Jakarta 
